\title{
The Chinese Liberal Camp in Post-June 4th China
}

\section{Feng Chongyi}

\section{OpenEdition}

\section{Journals}

\section{Electronic version}

URL: http://journals.openedition.org/chinaperspectives/4803

DOI: 10.4000/chinaperspectives.4803

ISSN: 1996-4617

\section{Publisher}

Centre d'étude français sur la Chine contemporaine

\section{Printed version}

Date of publication: 1 June 2009

Number of pages: $30-41$

ISSN: 2070-3449

\section{Electronic reference}

Feng Chongyi, «The Chinese Liberal Camp in Post-June 4th China », China Perspectives [Online] 2009/2 | 2009, Online since 01 June 2011, connection on 28 October 2019. URL : http:// journals.openedition.org/chinaperspectives/4803; DOI : 10.4000/chinaperspectives.4803

This text was automatically generated on 28 October 2019

(c) All rights reserved 


\section{The Chinese Liberal Camp in Post- June 4th China}

\section{Feng Chongyi}

\section{ABSTRACTS}

This paper is an assessment of Chinese liberal intellectuals in the two decades following June 4th. It provides an analysis of the intellectual development of Chinese liberal intellectuals; their attitudes toward the party-state, economic reform, and globalisation; their political endeavours; and their contributions to the project of constitutional democracy in China.

\section{AUTHOR}

\section{FENG CHONGYI}

Associate Professor in China Studies and Deputy Director of the China Research Centre at University of Technology, Sydney. 